Tersedia secara online di

\title{
Jurnal Tadris IPA Indonesia
}

Beranda jurnal : http://ejournal.iainponorogo.ac.id/index.php/jtii

\section{$\overline{\overline{\text { Artikel }}}$ \\ Efektivitas Model Pembelajaran Treffinger Berbasis Reading Aloud untuk Meningkatkan Kemampuan Menulis Literasi Ilmiah Peserta Didik MTS Kelas VIII}

\author{
Rahma Dhiyaul Imaroh ${ }^{1 *}$, Hanin Niswatul Fauziah ${ }^{2}$ \\ 1,2 Jurusan Tadris IPA, IAIN Ponorogo, Ponorogo
}

*Corresponding Address: rahmadhiyaulimaroh38@gmail.com

\section{Info Artikel}

Riwayat artikel:

Received: 4 Juni 2021

Accepted: 22 Juni 2021

Published:27 November 2021

\section{Kata kunci:}

Kemampuan menulis literasi ilmiah

Reading Aloud

Treffinger

\begin{abstract}
ABSTRAK
Penelitian ini bertujuan untuk mengetahui efektivitas model pembelajaran treffinger berbasis reading aloud terhadap kemampuan menulis literasi ilmiah peserta didik kelas VIII di MTs Negeri 4 Ponorogo. Penelitian ini menggunakan metode kuantitatif dengan desain Pretest-Posttest Control Group Design. Sampel pada penelitian ini adalah peserta didik kelas VIII A sebagai kelas eksperimen dan kelas VIII C sebagai kelas kontrol dengan jumlah 47 peserta didik. Penelitian ini dilakukan di MTs Negeri 4 Ponorogo. Instrumen pengambilan data menggunakan soal tes berupa essay yang diberikan kepada peserta didik sebelum dan sesudah diterapkan model pembelajaran treffinger berbasis reading aloud. Data dianalisis dengan uji- $t$ menggunakan aplikasi Minitab. Berdasarkan hasil penelitian diketahui bahwa nilai $P$-Value sebesar 0,000 . Karena nilai $P$-Value kurang dari 0,05 maka $\mathrm{H}_{0}$ ditolak. Hal ini menunjukkan bahwa terdapat perbedaan yang signifikan antara kemampuan menulis literasi ilmiah peserta didik yang menggunakan model pembelajaran treffinger berbasis reading aloud dengan kemampuan menulis literasi ilmiah peserta didik yang menggunakan model pembelajaran konvensional.
\end{abstract}

\section{PENDAHULUAN}

Ilmu Pengetahuan Alam (IPA) merupakan suatu ilmu yang mempelajari fenomena alam yang berupa fakta, konsep, dan hukum, yang dikonfirmasi melalui serangkaian penelitian. Pembelajaran IPA diharapkan dapat membantu peserta didik dalam memahami suatu fenomena alam. (Fitriyati et al., 2017). Perkembangan ilmu pengetahuan dan teknologi saat ini berkembang pesat yang memungkinkan berkembangnya informasi dari berbagai sumber, salah satunya kemampuan berkreativitas. Pemecahan masalah dan kemampuan kreatif dari bidang pendidikan telah menarik perhatian masyarakat. Hal tersebut dapat ditampilkan dalam kebijakan pendidikan dari berbagai kegiatan pembelajaran, kegiatan tersebut dimasukkan ke dalam kurikulum, perangkat pembelajaran atau strategi pembelajaran lainnya. (Eprilian, Dianty. Sudirman, A. Sofiani, 2015). 
Perkembangan dunia abad 21 mengalami kemajuan yang cepat, seperti adanya beberapa perubahan kualitas SDM dan proses bermasyarakat/ bersosial. Masyarakat yang berliterasi sains merupakan seseorang yang memiliki pengetahuan/ ilmu yang sangat luas dalam memahami fakta-fakta, khususnya hubungan antara sains, lingkungan, teknologi, dan masyarakat. Ilmu pengetahuan yang telah dimilikiakan menjadikan seseorang yang peka terhadap lingkungan yang ada di sekitar, dan dapat menyelesaikan masalah. (Pratiwi et al., 2019). Pembelajaran IPA pada abad 21 ini merupakan salah satu pembelajaran yang memiliki keterkaitan dan juga memiliki hubungan antar bagian-bagiannya. (Fitriani et al., 2021). Fenomena yang berhubungan dengan IPA yang terjadi di dunia ini tak lepas dari serangkaian konsep atau teori yang telah kita peroleh melalui proses ilmiah yang dilakukan oleh manusia. Dalam mencapai literasi sains, terlebih dahulu melakukan pengembangan dalam keterampilan literasi informasi. Keterampilan ini selaras dengan Standar Literasi Informasi dan termasuk menentukan konsep yang sesuai. Untuk secara efektif meningkatkan literasi informasi dan literasi sains, kita harus mengidentifikasi bagaimana peserta didik berinteraksi dengan teks ilmiah. (Hohenshell \& Hand, 2006). Mata pelajaran IPA itu sendiri terbagi menjadi 3 bagian ilmu yaitu ilmu fisika, ilmu kimia, dan ilmu biologi. Pada masing - masing bagian di dalamnya erat kaitannya dengan kehidupan yang ada di alam. (Jannah et al., 2021).

Pembelajaran IPA pada tingkat SMP tidak hanya sebagai disipin ilmu melainkan sebuah konsep keterpaduan mata pelajaran yang bersifat integrative science. (Zahro \& Pertiwi, 2021). Pendidikan IPA menghadapi banyak tantangan ketika mempelajari penulisan secara efektif tentang sains. Sebuah kinerja menulis yang kompeten membutuhkan penguasaan berbagai keahlian, termasuk tidak hanya keterampilan tata bahasa yang diperlukan dari semua penulis, tetapi memiliki ketrampilan retoris untuk secara efektif mengkomunikasikan klaim ilmiah dengan bukti yang sesuai. Pembelajaran IPA juga berperan penting dalam mengajarkan peserta didik mengenai kemampuan berpikir kritis, kreatif dan inovatif. (Pratiwi et al., 2019). Dalam pendidikan IPA, memiliki rasa hormat dan juga tanggung jawab merupakan salah satu bagian dari karakter sains yang didalamnya dapat dikembangkan melalui berbagai cara, yaitu seperti sedang berpikir ilmiah, membaca ilmiah, dan juga menulis tulisan ilmiah. Beberapa bagian karakter pada IPA yaitu peserta didik dapat mengembangkan kemampuan berpikir secara ilmiah, membaca literasi ilmiah dan juga menulis tulisan ilmiah. Sekarang ini kemampuan peserta didik dalam berliterasi sains khususnya literasi informasi dalam menulis ilmiah cenderung kurang aktif yang disebabkan berbagai alasan. Terdapat peserta didik yang rendah dalam membaca informasi pengetahuan, mencatat ilmu pengetahuan, peserta didik juga jarang dalam mengemukakan pendapat/ bertanya. Hal ini menjadikan peserta didik menjadi pasif akan hal-hal baru. Oleh karena itu sebagai pendidik, tantangan untuk mengelola pembelajaran di masa depan yaitu dengan cara mengembangkan dan juga meningkatkan literasi sains peserta didik agar terus percaya diri dan selalu bersikap kritis di berbagai permasalahan. (Hohenshell \& Hand, 2006).

Keterampilan yang harus dimiliki peserta didik di abad 21 ini adalah keterampilan kemampuan komunikasi, yang mana komunikasi ini akan membantu proses berlangsungnya literasi ilmiah. Terdapat kurikulum 2013 yang berisikan tentang esensi ilmiah/ pendekatan saintifik dalam pembelajaran, pada pendekatan ini diyakini dapat mengembangkan karakter dan sikap peserta didik serta dapat mengasah pengetahuan dan ketrampilan didik. (Awalin \& Ismono, 2021). Keterampilan menulis merupakan salah satu keterampilan berbahasa perlu mendapat perhatian karena memiliki dampak sangat penting dalam pembelajaran. (Cronje et al., 2013). Syamsuddin dalam (Wikanengsih, 2013) menjelaskan bahwa ketrampilan menulis merupakan cara berkomunikasi yang memiliki sifat khusus, yaitu dapat menciptakan suatu hubungan secara tidak langsung. Dalam kegiatan menulis, kita harus banyak mencari pengetahuan tentang ilmu menulis, serta dapatpula kita mengujicoba beberapa model pembelajaran sehingga model pembelajaran dalam menulis menjadi lebih berkembang. Pada 
dasarnya, bahasa merupakan salah satu alat komunikasi yang digunakan oleh seluruh manusia yang berfungsi sebagai alat interaksi dan beradaptasi dengan sesamanya. Kemampuan berbahasa juga digunakan sebagai alat dalam menyapa untuk mengenal kepribadian antara pribadi satu dengan yang lainnya. Bahasa telah dijadikan alat untuk menyampaikan pesan, pemikiran, atau gagasan kepada orang lain baik secara tertulis maupun lisan. Kita dapat melakukan komunikasi dengan menggunakan bahasa yang tertulis dengan tujuan dapat menuntut pemahaman tentang penggunaan ejaan serta harus mematuhi kaidah-kaidah dalam penulisan ilmiah. (Adnan, 2016).

Keterampilan menulis membutuhkan perhatian yang serius sejak menempuh pendidikan di sekolah menengah pertama. Keterampilan menulis sebagai awal proses mengenal menulis atau belajar menulis. Tanpa memiliki kemampuan menulis yang memadai sejak dini, seorang peserta didik akan mengalami kesulitan dalam belajar di masa mendatang, khususnya berliterasi sains. Peserta didik dibekali dengan memahami keterampilan ini melalui pembiasaan berlatih menulis dan praktik, dengan tujuan nanti ketika berada di jenjang pendidikan lebih tinggi akan lebih mudah dan optimal dalam meningkatkan kemampuan berliterasi ilmiah. Oleh karena itu sangatlah penting memiliki pengetahuan tentang kepenulisan ilmiah. (Sukardi \& Indah, 2015). Ilmu pengetahuan alam merupakan suatu ilmu yang mempelajari berbagai peristiwa dan gejala alam berdasarkan hasil dari suatu pengamatan dan juga percobaan. Ketepatan, kejelasan dan keringkasan merupakan aspek dalam kepenulisan yang harus diperhatikan. Memahami konsep dasar kepenulisan merupakan hal yang harus diketahui dalam kepenulisan ilmiah. (Adnan, 2016).

Menulis merupakan suatu proses kreatif menuangkan gagasan ke dalam tulisan. Kegiatan menulis akan dituangkan ke dalam bentuk suatu karangan. Suparmo dan Yunus dalam (Strube \& Lynch, 1984) berpendapat bahwa menulis sebagai suatu kegiatan penyampaian pesan (komunikasi) dengan menggunakan bahasa tulis sebagai medianya. Bernalar memiliki hubungan dalam berpikir. Selain itu dalam menggunakan bahasa, menulis merupakan perwujudan kegiatan berpikir yang berpengaruh pada tindakan. (Van Opstal \& Daubenmire, 2015). Kegiatan menulis merupakan suatu kegiatan berpikir yang dilakukan seseorang yang memiliki hubungan dengan bernalar, dengan adanya melakukan kegiatan menulis maka secara tidak langsung dapat memperbaiki kualitas belajar seseorang dan dapat menambah wawasan/ ilmu pengetahuan. Penggunaan bahasa dalam kegiatan menulis merupakan suatu wujud dari berpikir kritis yang berpengaruh pada kegiatan berliterasi. (Wikanengsih, 2013).

Berdasarkan pengamatan di salah satu sekolah yang ada di Ponorogo dengan guru IPA pada hari Selasa 24 November 2020, dalam proses pembelajaran IPA masih terdapat beberapa permasalahan, diantaranya yaitu kemampuan peserta didik dalam berliterasi sains khususnya dalam menulis literasi informasi masih sangat kurang, salah satu penyebabnya dikarenakan kurangnya variasi model pembelajaran yang digunakan dan juga keterbatasan waktu dalam pembelajaran. Oleh karena itu, peran guru dalam pembelajaran harus mampu meningkatkan kemampuan menulis literasi ilmiah peserta didik, sehingga peserta didik dapat memiliki wawasan yang luas terhadap literasi ilmiah.

Model pembelajaran treffinger merupakan salah satu model yang mangatasi permasalahan kurangnya kreativitas pada seorang peserta didik secara langsung, baik secara afektif maupun secara kognitif. Model ini dikembangkan oleh seseorang tokoh yang bernama treffinger yang didasarkan pada model belajar kreatifnya. (Nurjannah et al., 2020). Belajar kreatif merupakan salah satu cara dalam pembelajaran yang menjadikan kita selalu peka terhadap problematika yang terjadi. Selain itu dapat dilakukan dengan cara mengumpulkan beberapa informasi yang ada dan mengidentifikasinya, cermat dalam memberi solusi dan lain-lain. Model treffinger adalah model pembelajaran yang mengajak peserta didik untuk berpikir kreatif dalam menyelesaikan suatu permasalahan dan memberi solusi yang tepat. 
Pembelajaran model ini lebih mementingkan dari segi proses pembelajaran yang nantinya berperan untuk mendorong peserta didik dalam belajar kreatif. Belajar kreatif (creative learning) dapat diartikan sebagai suatu proses yang pembelajarannya dibuat secara komunikatif, sehingga peserta didik dapat menikmati situasi belajar yang menyenangkan. Dengan adanya model treffinger ini, akan mendorong kreativitas peserta didik untuk mencapai keterpaduan dalam pembelajaran dengan harapan dapat menunjukan saling ketergantungan dan berhubungan dalam mendorong belajar kreatif. Pada pembelajaran ini, peserta didik diberi penjelasan mengenai suatu konsep kemudian diberi persoalan yang lebih kompleks. Kelebihan dari model pembelajaran treffinger ini adalah dapat mengembangkan kemampuan peserta didik dalam berpikir kreatif dan kritis serta dapat mengembangkan kemampuan untuk menyesuaikan dengan pengetahuan yang baru. (Maygayanti et al., 2016).

Model pembelajaran treffinger ini didukung dengan salah satu metode pembelajaran yaitu reading aloud, yang memiliki arti membaca keras atau membaca nyaring. (Shadily Hassan, 2005). Teknik/ metode membaca seperti ini akan membantu peserta didik dalam memfokuskan kesiapan mental dan meningkatkan pemahaman materi. Metode reading aloud merupakan salah satu aktifitas dalam pembelajaran yang berfungsi untuk memahami informasi yang terdapat dalam bacaan, sebagai pendengar orang lain dalam memahami perasaan, informasi, serta pikiran. (Ustianingsih \& Riwayanti, 2016). Membaca merupakan proses yang kompleks, dan melibatkan sejumlah kegiatan fisik dan mental seseorang. Seorang pembaca yang baik adalah pembaca yang dapat memahami suatu bacaan secara keseluruhan dan dapat mengambil suatu kesimpulan dari bacaan. Membaca merupakan suatu proses yang bertujuan untuk mengenali atau mengidentifikasi teks bacaan dan mengingat kembali isi teks bacaan. (Ustianingsih \& Riwayanti, 2016). Model pembelajaran treffinger itu sendiri memiliki 3 tahapan, diantaranya Understanding Challenge, Generating Ideas, dan Preparing For Action. Model treffinger yang berbasis reading aloud ini merupakan salah satu alternatif dalam mendukung pembelajaran yang akan membantu meningkatkan kemampuan peserta didik dalam menulis literasi ilmiah. Dengan adanya menerapkan model pembelajaran treffinger berbasis reading aloud pembelajaran menjadi lebih aktif, kreatif dan efektif sehingga dapat meningkatkan kemampuan yang dimiliki peserta didik dalam berliterasi sains. Tujuan dari penelitian ini adalah untuk mengetahui efektivitas model pembelajaran treffinger berbasis reading aloud untuk meningkatkan kemampuan menulis literasi ilmiah peserta didik kelas VIII di MTs Negeri 4 Ponorogo.

\section{METODE}

Penelitian ini menggunakan metode penelitian metode kuantitatif dengan desain Pretest-Postest Control Group Design. Sampel pada penelitian ini adalah kelas VIII A sebagai kelas eksperimen dan kelas VIII C sebagai kelas kontrol dengan jumlah 47 peserta didik yang dipilih secara random. Penelitian ini dilakukan di MTs Negeri 4 Ponorogo semester II/genap tahun ajaran 2020/2021. Indikator dari kemampuan menulis ilmiah yang digunakan pada penelitian ini adalah: jelas, jujur, runtut, informatif, akurat, dan mengedepankan sikap ilmiah.

Tabel 1. Desain Penelitian Pretest-Postest Control Group Design

\begin{tabular}{c|c|c|c}
\hline Kelompok & Pretest & Perlakuan & Posttest \\
\hline Eksperimen & $\mathrm{O}_{1}$ & $\mathrm{X}_{1}$ & $\mathrm{O}_{2}$ \\
\hline Kontrol & $\mathrm{O}_{3}$ & $\mathrm{X}_{2}$ & $\mathrm{O}_{4}$ \\
\hline
\end{tabular}

Keterangan:

$\mathrm{O}_{1}=$ Pre-test yang diberikan sebelum perlakuan pada kelas eksperimen

$\mathrm{O}_{2}=$ Post-test yang diberikan setelah penerapan perlakuan pada kelas eksperimen

$\mathrm{O}_{3}=$ Pre-test yang diberikan sebelum perlakuan pada kelas kontrol

$\mathrm{O}_{4}=$ Post-test yang diberikan setelah penerapan perlakuan pada kelas kontrol

$\mathrm{X}_{1}=$ Perlakuan berupa pembelajaran dengan menggunakan model pembelajaran treffinger 
berbasis reading aloud

$\mathrm{X}_{2}=$ Perlakuan berupa pembelajaran dengan menggunakan model pembelajaran Konvensional

Penelitian ini dimulai dengan memberikan soal pre-test berupa essay yang ditujukan kepada kelas eksperimen dan kelas kontrol yang sebelumnya diberi perlakuan. Selanjutnya peneliti menerapkan model pembelajaran treffinger berbasis reading aloud pada kelas eksperimen dan model pembelajaran konvensional pada kelas kontrol. Setelah itu diberikan soal posttest yang digunakan untuk mengetahui perbedaan kemampuan menulis literasi ilmiah peserta didik di kelas eksperimen dan kelas kontrol.

Setelah mendapatkan data penelitian, kemudian dilakukan analisis dengan menggunakan uji-t two tailed dan uji-t one tailed dengan bantuan aplikasi Minitab. Uji- $t$ two tailed digunakan untuk mengetahui perbedaan kemampuan menulis ilmiah peserta didik yang menggunakan model pembelajaran treffinger berbasis reading aloud dengan peserta didik yang menggunakan model pembelajaran konvensional. Jika hasil dari $\mathrm{H}_{0}$ ditolak maka dilanjutkan analisis dengan menggunakan uji-t one tailed. Uji-t one tailed digunakan untuk mengetahui lebih baik mana antara peserta didik yang menggunakan model pembelajaran treffinger berbasis reading aloud dengan peserta didik yang menggunakan model pembelajaran konvensional.

\section{HASIL DAN PEMBAHASAN}

Berdasarkan data hasil penelitian diketahui bahwa nilai rata-rata kemampuan menulis literasi ilmiah kelas eksperimen lebih tinggi dibandingkan dengan kelas kontrol. (Gambar 1). Nilai rata-rata kelas eksperimen adalah sebesar 91 sedangkan kelas kontrol adalah sebesar 77.

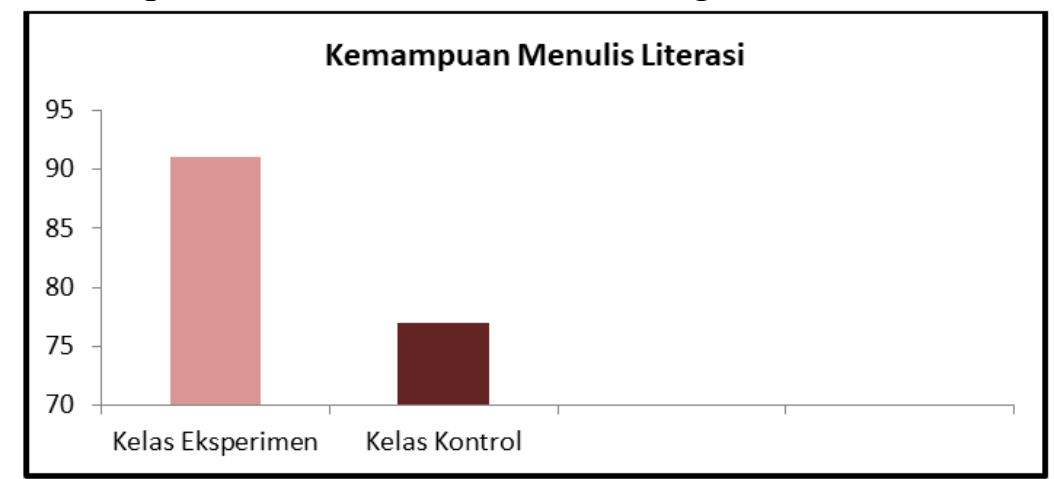

Gambar 1. Hasil Nilai Rata-rata Kemampuan Menulis Literasi Ilmiah Kelas Eksperimen dan Kelas Kontrol

Kemampuan menulis literasi ilmiah pada penelitian ini memiliki indikator, diantaranya yaitu: jelas, jujur, runtut, informatif, akurat, dan mengedepankan sikap ilmiah. Nilai masingmasing pada indikator kemampuan menulis literasi ilmiah kelas eksperimen dan kelas kontrol disajikan pada gambar 2 .

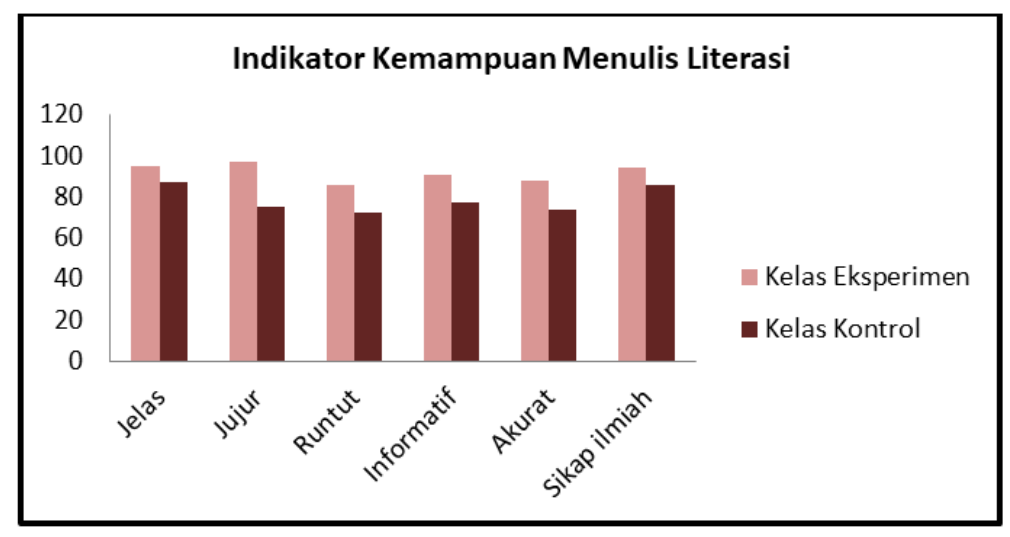


Gambar 2. Hasil Analisis Indikator Kemampuan Menulis

Literasi Ilmiah Kelas Eksperimen dan Kelas Kontrol

Pada gambar 2 dapat diketahui bahwa nilai semua indikator kemampuan menulis literasi ilmiah kelas eksperimen lebih tinggi dibandingkan dengan nilai kemampuan menulis literasi ilmiah kelas kontrol. Nilai tertinggi untuk kelas eksperimen terdapat pada indikator "jujur" dengan nilai sebesar 97, sedangkan nilai terendah untuk kelas eksperimen terdapat pada indikator "runtut" dengan nilai sebesar 86. Pada kelas kontrol nilai tertinggi terdapat pada indikator "jelas" dengan nilai sebesar 87 , sedangkan nilai terendah untuk kelas kontrol terdapat pada indikator "runtut" dengan nilai sebesar 72,5.

Untuk mengukur peningkatan kemampuan menulis literasi sebelum dan sesudah diterapkannya model pembelajaran treffinger berbasis reading aloud yang telah dilaksanakan pada kelas eksperimen, maka dilakukan penghitungan menggunakan $\mathrm{N}$-gain dengan rumus sebagai berikut: (Rohaenitasari, 2013).

$$
N \text {-gain }=\frac{\text { nilai post test }- \text { nilai pre test }}{\text { nilai ideal }- \text { nilai pre test }}
$$

Adapun hasil dari penghitungan $\mathrm{N}$-gain, Pretest dan Posttest adalah sebagai berikut:

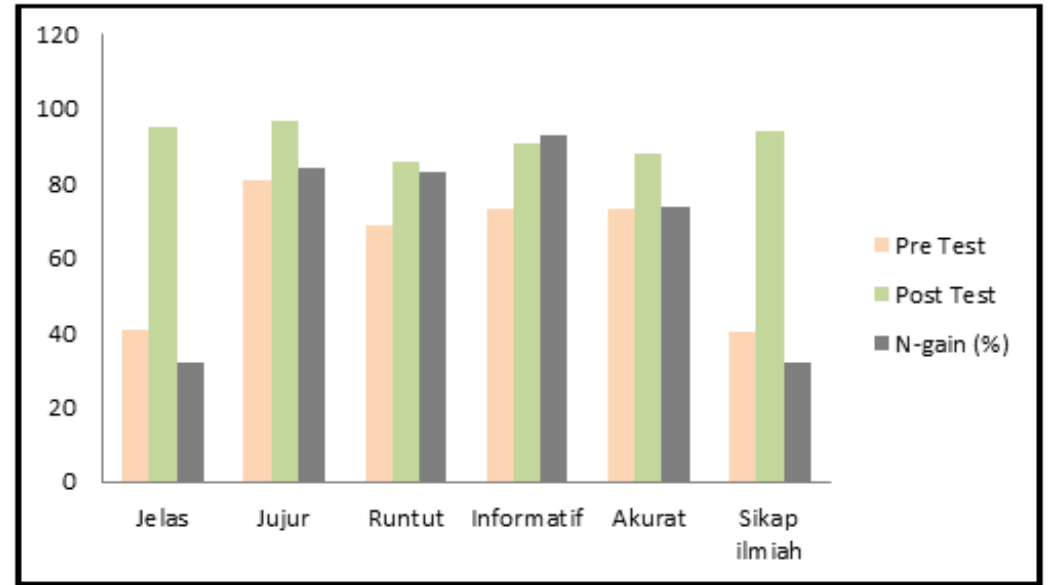

Gambar 3. Nilai Pretest, Posttest, dan N-gain Indikator Kemampuan Menulis Literasi Ilmiah Kelas Eksperimen

Berdasarkan gambar 3 diketahui bahwasanya semua indikator dari kemampuan menulis literasi ilmiah di MTs Negeri 4 Ponorogo pada mata pelajaran IPA mengalami adanya peningkatan setelah diterapkannya model pembelajaran treffinger berbasis reading aloud. Nilai $N$-gain pada indikator "jelas" sebesar 0,32 dengan kategori cukup efektif. Nilai $\mathrm{N}$-gain pada indikator "jujur" sebesar 0,84 dengan kategori efektif. Nilai $\mathrm{N}$-gain pada indikator "runtut" sebesar 0,83 dengan kategori efektif. Nilai $N$-gain pada indikator "informatif" sebesar 0,93 dengan kategori efektif. Nilai $\mathrm{N}$-gain pada indikator "akurat" sebesar 0,74 dengan kategori efektif. Nilai $\mathrm{N}$-gain pada indikator "mengedepankan sikap ilmiah" sebesar 0,32 dengan kategori cukup efektif. Hal ini menunjukkan bahwa model pembelajaran treffinger berbasis reading aloud cukup efektif dalam meningkatkan kemampuan menulis literasi ilmiah peserta didik kelas VIII pada mata pelajaran IPA di MTs Negeri 4 Ponorogo. Kategori nilai dari $N$-gain adalah sebagai berikut: (Nismalasari, 2016).

Tabel 2. Kategori $N$-gain

\begin{tabular}{c|c} 
Nilai Gain & Interpretasi \\
\hline $0,70 \leq \mathrm{g} \leq 1,00$ & Efektif \\
\hline $0,30 \leq \mathrm{g} \leq 0,70$ & Cukup Efektif \\
\hline $0,00<\mathrm{g}<0,30$ & Tidak Efektif \\
\hline $\mathrm{g}=0,00$ & Tidak Terjadi Peningkatan \\
\hline$-1,00 \leq \mathrm{g} \leq 0,00$ & Terjadi Penurunan \\
\hline
\end{tabular}

Berdasarkan hasil penelitian diketahui bahwa nilai rata-rata kemampuan menulis ilmiah kelas eksperimen sebesar 91 dan pada kelas kontrol sebesar 77. Hasil ini menunjukkan bahwa terdapat perbedaan kemampuan menulis literasi ilmiah peserta didik yang menggunakan 
model pembelajaran treffinger berbasis reading aloud dengan peserta didik yang menggunakan model pembelajaran konvensional. Berdasarkan hasil dari uji-t (two-tailed) diketahui $P$-Value memiliki nilai sebesar 0,000 . Dikarenakan nilai $P$-Value kurang dari 0,05 maka dinyatakan $\mathrm{H}_{0}$ ditolak. Hal ini menunjukkan bahwa terdapat perbedaan yang signifikan terhadap kemampuan menulis literasi ilmiah antara kelas eksperimen dan kelas kontrol pada mata pelajaran IPA di MTs Negeri 4 Ponorogo. Berdasarkan hasil uji-t (one-tailed) diketahui bahwa nilai P-Value sebesar 0,000. Karena nilai P-Value kurang dari 0,05 maka $\mathrm{H}_{0}$ dinyatakan ditolak. Hal ini menunjukkan bahwa kemampuan menulis literasi ilmiah peserta didik pada kelas eksperimen yang menggunakan model pembelajaran treffinger berbasis reading aloud lebih baik dibandingkan dengan kemampuan menulis literasi ilmiah peserta didik pada kelas kontrol, yang menggunakan model pembelajaran konvensional.

Model pembelajaran treffinger berbasis reading aloud membantu peserta didik dalam merangsang pemikiran kreatif dan berperilaku aktif ketika berada di kelas. (Maygayanti et al., 2016). Peserta didik dapat dengan mudah memahami materi dan juga permasalahan yang ada. Selain itu, peserta didik sangat senang dan memiliki antusias ketika peserta didik diberi kesempatan dalam menyampaikan pemikiran kreatifnya. (Wirahayu et al., 2018). Dengan demikian peserta didik tidak mengalami kejenuhan selama menjalani proses pembelajaran. Peserta didik menjadi lebih percaya diri setelah menyelesaikan permasalahan dalam kehidupan sehari-hari. Pembelajaran ini berbasis membaca literasi dengan tujuan ketika peserta didik mengikuti pembelajaran, peserta didik tidak dalam kondisi tidak mengetahui apa-apa. Semakin banyak peserta didik membaca suatu literasi maka pengetahuannya akan semakin bertambah. Model pembelajaran treffinger berbasis reading aloud dapat dijadikan sebuah inovasi dalam dunia pendidikan, dikarenakan dengan menggunakan model pembelajaran treffinger berbasis reading aloud, akan menjadikan peserta didik lebih mudah dalam mempelajari dan memahami materi yang diberikan, mempunyai pikiran yang kreatif dan membangun kerjasama antar kelompok. (Mundziroh et al., 2013). Model pembelajaran treffinger berbasis reading aloud ini juga dapat digunakan diberbagai situasi, dengan harapan agar peserta didik dapat mengembangkan pemikiran kritis dan juga kreatif. (EPRILIAN, DIANTY. Sudirman, A. Sofiani, 2015).

Di dunia pendidikan membiasakan diri dengan menulis sangatlah penting dan dapat dikatakan sebagai bagian dari disiplin ilmu. Di samping itu proses menulis dapat diartikan sebagai sarana dalam berpikir kreatif dalam memperluas pengetahuan dan wawasan serta mendapat inspirasi. (Sardila, 2015). Kemampuan menulis literasi ini juga akan membantu meningkatkan kebiasaan gaya belajar peserta didik. Dengan adanya mempelajari literasi khususnya pada sains, peserta didik akan terbiasa untuk berpikir kreatif dan juga kritis. Kemampuan menulis ini erat kaitannya dengan teks, yang mana teks itu sendiri merupakan satuan bahasa yang dimediakan secara tertulis maupun secara lisan dengan maksud untuk mengungkapkan makna suatu konsep. (WIDANINGSIH, 2014).

Hasil penelitian ini sejalan dengan penelitian yang telah dilakukan oleh Wahyu Hidayatullah, dijelaskan bahwa model pembelajaran treffinger ini dapat meningkatkan pemikiran peserta didik menjadi lebih aktif dan kreatif ketika mengikuti pembelajaran. Dalam jurnal penelitian yang berjudul "Keefektifan Model Pembelajaran treffinger Berbantuan LKS Untuk Meningkatkan Hasil Belajar" diuraikan bahwasanya model pembelajaran treffinger ini terbukti efektif saat digunakan dalam pembelajaran dalam meningkatkan hasil belajar peserta didik dan juga adanya peningkatan dalam ketercapaian beberapa aspek, diantaranya aspek kognitif, aspek afektif dan aspek psikomotorik. (Hidayatulloh \& Nurhayati, 2016).

Hasil penelitian ini juga didukung dengan penelitian yang dilakukan oleh Imas Teti Rohaeti dengan judul penelitian "Penerapan Model Treffinger pada Pembelajaran Matematika untuk Meningkatkan Kemampuan Berpikir Kreatif Siswa SMP” Jurnal Universitas Pendidikan Indonesia pada tahun 2013. Menurut Efendi menyatakan bahwa 
model pembelajaran treffinger dapat mengembangkan kompetensi strategis siswa SMP. Hal ini sejalan dengan penelitian yang telah dilakukan dengan fokus kemampuan menulis literasi ilmiah. Kemampuan menulis literasi ilmiah peserta didik dapat meningkat dengan adanya model pembelajaran treffinger berbasis reading aloud. (Teti Rohaeti, 2013). Menurut Retno pembelajaran yang menggunakan reading aloud sebagai salah satu metode pembelajaran, membuat pemahaman peserta didik meningkat dan memiliki rata-rata nilai yang tinggi. Berdasarkan penelitian yang dilakukan oleh Yuswanti Ariani Wirahayu, Hendri Purwito, Juarti pada Januari tahun 2018 yang berjudul "Penerapan Model Pembelajaran Treffinger Dan Ketrampilan Berpikir Divergen Mahasiswa" Jurnal terbitkan oleh Jurusan Geografi, Fakultas Ilmu Sosial, Universitas Negeri Malang Jurnal Pendidikan Geografi: Kajian, Teori, dan Praktik dalam Bidang Pendidikan dan Ilmu Geografi Tahun 23, Nomor 1 diketahui bahwa penggunaan dari model pembelajaran treffinger ini mempengaruhi kemampuan berpikir dan juga sikap pada seorang mahasiswa. Selain itu, model ini dapat dikatakan paling fleksibel, reliabel dan juga aplikabel dalam pembelajaran. (Wirahayu et al., 2018).

Berdasarkan hasil penelitian yang telah dilakukan, menunjukkan bahwa terdapat peningkatan kemampuan menulis literasi ilmiah peserta didik. Dari beberapa indikator kemampuan menulis literasi ilmiah yang paling berperan dalam penelitian ini adalah pada indikator "jujur" memiliki nilai $N$-gain sebesar 0,84 dengan kategori efektif. Dengan demikian peserta didik mampu menyelesaikan masalah sesuai dengan fakta/kejadian yang sebenarnya dengan dasar berliterasi ilmiah setelah diterapkannya model pembelajaran treffinger berbasis reading aloud. Pada proses pembelajaran, peserta didik diberikan sebuah permasalahan nyata yang ada di kehidupan sehari-hari yang sesuai dengan materi pembelajaran, sehingga peserta didik dapat menuliskan solusi yang sesuai fakta/ kejadian. Dengan dilakukannya penelitian ini, diharapkan model pembelajaran treffinger yang berbasis reading aloud dapat menjadi salah satu model alternatif yang dipilih oleh guru dan calon guru dalam melangsungkan kegiatan pembelajaran yang kreatif, aktif dan inovatif serta dapat meningkatkan kemampuan peserta didik dalam pembiasaan menulis literasi ilmiah.

\section{KESIMPULAN}

Berdasarkan hasil penelitian yang telah dilakukan, dapat diambil kesimpulan bahwasanya terdapat perbedaan yang signifikan pada kemampuan menulis literasi ilmiah peserta didik yang menggunakan model pembelajaran treffinger berbasis reading aloud dengan peserta didik yang menggunakan model pembelajaran konvensional. Pembelajaran yang menggunakan model pembelajaran treffinger berbasis reading aloud lebih baik dibandingkan dengan kelas yang menggunakan pembelajaran konvensional. Dengan demikian dapat dikatakan bahwa model pembelajaran treffinger berbasis reading aloud ini efektif untuk meningkatkan kemampuan menulis literasi ilmiah peserta didik.

\section{REFERENSI}

Adnan, N. I. dan E. H. (2016). Pengetahuan Kebahasaan Dan Keterampilan Menulis Ilmiah Mahasiswa Fkip-Unsa. Journal of Chemical Information and Modeling, 53(9), 16891699. https://doi.org/10.1017/CBO9781107415324.004

Awalin, N. A., \& Ismono. (2021). The Implementation of Problem Based Learning Model With STEM (Science, Technology, Engineering, Mathematics) Approach to Train Students' Science Process Skills of XI Graders on Chemical Equilibrium Topic. INSECTA Integrative Science Education and Teaching Activity Journal, 2(1), 1-14.

Cronje, R., Murray, K., Rohlinger, S., \& Wellnitz, T. (2013). Using the science writing heuristic to improve undergraduate writing in biology. International Journal of Science Education, 35(16), 2718-2731. https://doi.org/10.1080/09500693.2011.628344

Eprilian, Dianty. Sudirman, A. Sofiani, S. R. (2015). Penerapan Model Treffinger Untuk 
Meningkatkan Aktivitas Dan Hasil Belajar Ipa. PGSD UPP Metro FKIP UNILA Jln. Budi Utomo No. 4 Metro Selatan, Kota Metro Selatan, Kota Metro.

Fitriani, F., Fadly, W., \& Faizah, U. N. (2021). Analisis Keterampilan Berpikir Analitis Siswa pada Tema Pewarisan Sifat. Jurnal Tadris IPA Indonesia, 1(1), 55-67.

Fitriyati, I., Hidayat, A., \& Munzil. (2017). Pengembangan Perangkat Pembelajaran IPA untuk Meningkatkan Kemampuan Berpikir Tingkat Tinggi dan Penalaran Ilmiah Siswa Sekolah Menengah Pertama. Jurnal Pembelajaran Sains, 1(1), 27-34.

Hidayatulloh, W., \& Nurhayati, S. (2016). Keefektifan Model Pembelajaran Treffinger Berbantuan Lembar Kerja Siswa Untuk Meningkatkan Hasil Belajar. Jurnal Inovasi Pendidikan Kimia, 10(1), 1712-1720.

Hohenshell, L. M., \& Hand, B. (2006). Writing-to-learn strategies in secondary school cell biology: A mixed method study. International Journal of Science Education, 28(2-3), 261-289. https://doi.org/10.1080/09500690500336965

Jannah, F., Fadly, W., \& Aristiawan, A. (2021). Analisis Karakter Rasa Ingin Tahu Siswa pada Tema Struktur dan Fungsi Tumbuhan. Jurnal Tadris IPA Indonesia, 1(1), 1-16.

Maygayanti, N. M. E., Agustini, K., \& Sunarya, I. M. G. (2016). Studi Komparatif Penggunaan Model Pembelajaran Treffinger Dan Problem Based Learning Terhadap Hasil Belajar TIK Siswa Kelas XI Di SMA Laboratorium Undiksha Singaraja. Kumpulan Artikel Mahasiswa Pendidikan Teknik Informatika (KARMAPATI), 5(2), 110.

Mundziroh, S., Sumarwati, S., \& Saddhono, K. (2013). Peningkatan Kemampuan Menulis Cerita Dengan Menggunakan Metode Picture and Picture Pada Siswa. Jurnal Penelitian Bahasa, Sastra Indonesia, Dan Pengajarannya, 1(2), 318-327.

Nismalasari. (2016). Penerapan Model Pembelajaran Leraning Cycle Terhadap Keterampilan Proses Sains Dan Hasil Belajar Siswa Pada Pokok Bahasan Getaran Harmonis. Jurnal Edu Sains 2, 83.

Nurjannah, H., Saputro, A., Geografi, J., Matematika, F., \& Ilmu, D. A. N. (2020). The Application of The Treffinger Learning Model in Learning Geography. 19(1), 113-127.

Pratiwi, S. N., Cari, C., \& Aminah, N. S. (2019). Pembelajaran IPA Abad 21 dengan Literasi Sains Siswa. Jurnal Materi Dan Pembelajaran Fisika (JMPF), 9, 34-42.

Rohaenitasari, W. (2013). Peningkatan Hasil Belajar Siswa SMA Melalui Praktikum Dalam Model Pembelajaran Learning Cycle 7E Pada Materi Stoikiometri Universitas Pendidikan Indonesia. Repository.Upi.Edu Perpustakaan.Upi.Edu, 9, 40.

Sardila, V. (2015). Strategi Pengembangan Linguistik Terapan Melalui Kemampuan Menulis Biografi Dan Autobiografi : Sebuah Upaya Membangun Keterampilan Menulis Kreatif Mahasiswa. Journal Pemikiran Islam, 40(2), 110-117.

Shadily Hassan, E. J. M. (2005). Kamus Inggris Indonesia (Cet. 26). PT Gramedia.

Strube, P., \& Lynch, P. P. (1984). Some influences on the modern science text: Alternative science writing. European Journal of Science Education, 6(4), 321-338. https://doi.org/10.1080/0140528840060403

Sukardi, B., \& Indah. (2015). Peningkatan Kemampuan Menulis Artikel Ilmiah Populer Siswa Kelas Ix Smp Negeri I Bringin Dengan Pembelajaran Saintifik Berbasis Media Massa. Jurnal Unimus, 118-141.

Teti Rohaeti, I. (2013). Penerapan Model Treffinger Pada Pembelajaran Matematika Untuk Meningkatkan Kemampuan Berpikir Kreatif siswa SMP. Universitas Pendidikan Indonesia, repository, 1-10.

Ustianingsih, L., \& Riwayanti, L. P. (2016). Pengaruh Metode Reading Aloud Terhadap Kemampuan Membaca Pemahaman Mahasiswa Jurusan Bahasa Jepang. Jurnal Ilmiah Bahasa Dan Sastra, 3 No 2(23557083), 542-551.

van Opstal, M. T., \& Daubenmire, P. L. (2015). Extending Students' Practice of 
Metacognitive Regulation Skills with the Science Writing Heuristic. International Journal of Science Education, 37(7), 1089-1112. https://doi.org/10.1080/09500693.2015.1019385

Widaningsih. (2014). Strategi Curiosity Based Learning dalam pembelajaran menulis teks ilmiah populer di kelas VII SMP Negeri 3 Bandung. Universitas Pendidikan Indonesia, volume $3 \mathrm{~N}, 45-59$.

Wikanengsih, W. (2013). Model Pembelajaran Neurolinguistic Programming Berorientasi Karakter Bagi Peningkatan Kemampuan Menulis Siswa SMP. Jurnal Ilmu Pendidikan Universitas Negeri Malang, 19(2), 104445.

Wirahayu, Y. A., Purwito, H., \& Juarti, J. (2018). Penerapan Model Pembelajaran Treffinger dan Ketrampilan Berpikir Divergen Mahasiswa. Jurnal Pendidikan Geografi, 23(1), 3040. https://doi.org/10.17977/um17v23i12018p030

Zahro, R., \& Pertiwi, F. N. (2021). Analisis Komparasi Ketrampilan Inferensi Peserta Didik Ditinjau dari Penerapan Model Pembelajaran Problem Solving dengan Pendekatan Saintifik pada Pembelajaran IPA. Jurnal Tadris IPA Indonesia, 1(1), 23-33. 